\title{
Discussion Forums as a Learning Material in Higher Education Institutions
}

\author{
Hakan Kilinc $^{(\varpi)}$ and Hakan Altinpulluk \\ Anadolu University, Open Education Faculty, Turkey \\ hakankilinceanadolu.edu.tr
}

\section{ABSTRACT}

Discussion forums, which have more features among the tools used in the online group discussion process, are the most preferred learning tool in this process. Instructors, from elementary school to college often use online discussion forums to encourage interaction and complex thinking that are not always effective in traditional face-to-face learning situations. Discussion forums are a tool that enables learners to create information, collaborate and interact simultaneously or asynchronously in the online learning environment. In addition, it allows more time for all learners to reflect on their own ideas and respond to other learners in the learning process. However, it is seen that there are not enough studies on the usability of discussion forums, which are an effective learning material used in online learning environments. From this point of view, this study investigates the usability of discussion forums in online learning environments. In this study, in which qualitative research method was used, the opinions of 8 field experts determined by purposeful sampling method were consulted in the context of the use of discussion forums in online learning environments. With the investigation of the usability of discussion forums in online learning environments, it is predicted that the efficiency to be obtained from these environments will increase.

Keywords: discussion forums, online learning, online learning environments, qualitative research

Cite this article as: Kilinc, H., \& Altinpulluk, H. (2021). Discussion Forums as a Learning Material in Higher Education Institutions. International Journal of Higher Education Pedagogies, 2(1), 1-9. https://doi.org/10.33422/ijhep.v2i1.25

\section{Introduction}

According to Vygotsky (1967), social and cognitive development takes place first on the social plane where learner and instructor interactions exist; After this stage, social content and context are transformed into the individual plane and internalized. Cognitive processes such as clarifying, elaborating, defending and integrating opinions and thoughts become operational with the dialogues carried out in this process (Jonassen et al., 1995). In other words, the creation of meaning or the construction of information takes place as long as thoughts are expressed, reflected and discussed. This communication process, which takes place orally in the traditional environment, can also be done in written form with the spread of online environments. The written communication opportunity provided in online learning environments ensures that the communication process carried out in these environments is carried out asynchronously. Along with asynchronous communication, online learning environments allow the application of the online group discussion technique that allows learners to exchange information, develop creative ideas, create a better understanding and participate in the learning process in a more interactive way (Knowlton, 2002). Group discussions in online learning environments can be carried out by e-mail, discussion forums, conference systems, Wikis and other Web 2.0 technologies (Black et al., 2011). Discussion

(C) The Author(s). 2021 Open Access. This article is distributed under the terms of the Creative Commons Attribution 4.0 International License, which permits unrestricted use, distribution, and redistribution in any medium, provided that the original author(s) and source are credited. 
forums, which have more features among the tools used in the online group discussion process, are the most preferred learning tool in this process (Schiek ve Ullrich, 2019).

In online learning environments, learners are asked to discuss and interact in the learning process (Altinpulluk et al., 2019; Kilinc ve Yuzer, 2015; Loncar et al., 2014). Instructors, from elementary school to college often use online discussion forums to encourage interaction and complex thinking that are not always effective in traditional face-to-face learning situations (Chen and Wang, 2009). Discussion forums are a tool that enables learners to create information, collaborate and interact simultaneously or asynchronously in the online learning environment (So, 2009). Gerosa et al. (2010) defines the online discussion forum as an asynchronous textual communication tool used to learn better. Online discussion forums help less confident learners to voice their opinions. In addition this, it allows more time for all learners to reflect on their own ideas and to respond to other learners in the learning process. Loncar et al. (2014) stated that, due to the lack of face-to-face communication in online learning environments, online discussion forums will be used more in these environments in the future. Green et al. (2014), in a study they conducted, concluded that discussion forums are the most used component of learning management systems, which are widely used in online learning processes. The following seven components have been underlined by Hew and Cheung (2008) in order to make discussion forums more efficient. These components

- presenting their own views or experiences,

- ask questions,

- show appreciation,

- to create a basis for discussions,

- suggest a new direction to discussions,

- inviting people to contribute personally,

- summarizing the discussions that took place during the process,

is like. At this point, it can be stated that the trainers should pay attention to these elements in the learning activities carried out in online discussion forums.

Learners who interact with each other are mainly involved in the process of generating ideas, exposing these ideas to others' comments and criticism, and reshaping the ideas in the light of the discussions they make in the process (Rowntree, 1995). This process is consistent with the idea that learning emerges from efforts to create common meanings (Roschelle, 1992). In this context, the use of online discussion forums that allow simultaneous and asynchronous interaction in online learning environments, such as online group discussions, to enable learners to participate in a social and interactive learning process and to form a questioning community. In addition, in the relevant literature, it has been observed that the studies conducted on how discussion forums should be designed in online learning processes, how to increase participation and what their limitations might be were insufficient. From this point of view, this study investigates the usability of discussion forums in online learning environments. In this study, which was designed with the qualitative research method, the following research question was asked to the participants who were determined through purposeful sampling:

- How can discussion forums be used as an effective learning material in online learning environments?

- What are the advantages of discussion forums in online learning processes?

- What are the drawbacks of discussion forums in online learning processes? 


\section{Method}

In this study, phenomenology method was used in order to obtain the opinions of field experts on the usability of discussion forums in online learning environments. Phenomenology pattern, a research design that focuses on phenomena that we are aware of but do not have an in-depth and detailed understanding, is an inquiry strategy in which the researcher tries to define the essence of human experiences about a phenomenon explained by the participants (Creswell, 2003).

\subsection{Working Group}

In qualitative research, purposeful sampling is preferred over random sampling, as it is recommended to keep the sample group small in order to investigate the sample in depth (Miles \& Huberman, 1994). In order to be suitable for the purpose of the study, criterion sampling method, which is one of the purposeful sampling methods, was preferred. The basic understanding in the criteria sampling method is to study all situations that meet a predetermined set of criteria. At this point, a set of previously prepared criteria can be used, as well as developed by the researcher (Yıldırım \& Şimşek, 2011). In this study, the criteria for participants to be open and distance learning experts were taken into account. In this context, the demographic information of the experts who contributed to the study are shown in Table 1.

Table 1.

Demographic information of the participants

\begin{tabular}{ccccc}
\hline Participant & Age & Gender & Title & $\begin{array}{c}\text { Seniority } \\
\text { (Year) }\end{array}$ \\
\hline P1 & 68 & Male & Doctor & 45 \\
P2 & 35 & Male & Doctor & 10 \\
P3 & 48 & Male & Doctor & 26 \\
P4 & 31 & Male & Doctor & 6 \\
P5 & 26 & Female & Doctor & 8 \\
P6 & 32 & Female & Doctor & 14 \\
P7 & 39 & Female & Doctor & 8 \\
\hline
\end{tabular}

\subsection{Data collection tool}

Structured interview questions were directed to open and distance learning experts in order to get their views on the usability of discussion forums in online learning environments. Before the interviews, the content validity of the structured interview form was obtained by obtaining the opinions of three experts working on qualitative research methods and the final version was given. The structured interview form, which was finalized in line with the opinions of field experts, was created through Google Docs. The interview form consists of 3 open-ended questions. Open-ended questions were prepared in line with the research questions prepared within the scope of the research purpose.

\subsection{Data Analysis}

Content analysis method was used to analyze the data. The main purpose in content analysis is to reach the concepts and relationships that can explain the collected data. For this purpose, the collected data must first be conceptualized, then organized in a logical manner according to the emerging concepts and the themes explaining the data must be determined accordingly (Yıldırım ve Şimşek, 2011). Content analysis to be carried out within the scope of the study was carried out using NVIVO 12 qualitative data analysis program. The codes were 
determined as a result of the content analysis of the raw data obtained from the interviews. The codes obtained are presented in the findings section of the study.

\section{Findings}

The findings obtained in the light of the questions asked to the participants within the scope of this study are given below.

\subsection{Opinions of Field Experts on How the Discussion Forums Can Be Used as an Effective Learning Material}

Within the scope of the study, firstly, how discussion forums can be an effective learning material in online learning environments was emphasized. In this context, the opinions obtained from the participants are shown in Figure 1.

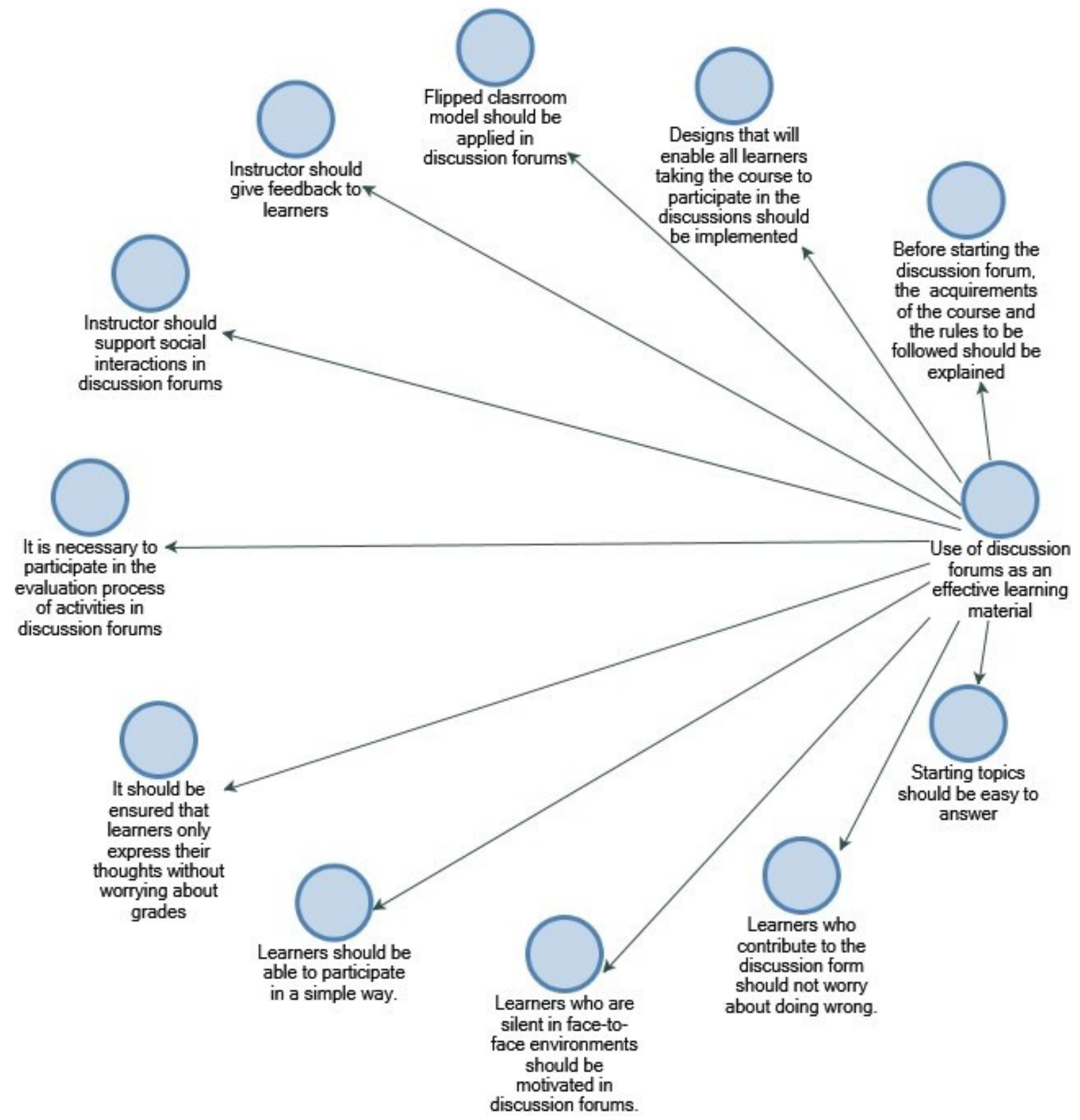

Figure 1: Use of discussion forums as an effective learning material

At this point, one of the sub-themes highlighted is "Instructor should give feedback to learners". The views highlighted under this sub-theme are as follows: 
“...The instructor should not neglect feedbacks to support the learners.” P1

"...These forums should be constantly checked by moderators and feedback should be made without delay to learners' views. Otherwise, the student will feel lonely and delay participation in the forums. " $\mathrm{P} 3$

"...In the discussion forms, the instructor should be guided." P4

Another sub-theme highlighted by the participants was the theme "Instructor should support social interactions in discussion forums". The views obtained under this theme are as follows:

"...Discussion forums should aim to enable learners to exchange ideas among themselves and to ensure the active participation of other learners. At this point, instructor should support the relationships between learners." $\mathrm{P} 6$

"The role of the instructors should be to motivate learners to participate in discussion forums in a variety of ways." $\mathrm{P} 7$

Another sub-theme highlighted under the main theme of Use of discussion forums as an effective learning material is "Flipped clasrroom model should be applied in discussion forums". The views obtained under this theme are as follows:

"...A learner's prior research on the topic given in a discussion form will both prepare the ground for the learner to express herself comfortably and to express her thoughts on the subject with more concrete expressions." $\mathrm{P} 2$

"...Discussion forums can be used in preparation for the lesson to attract students' attention to the lesson. It can also be used to consolidate the information learned in the course."P5

\subsection{Views of Field Experts on the Advantages of Discussion Forums}

Within the scope of the study, the opinions of field experts were consulted on the advantages of discussion forums in online learning environments. The views obtained in this context are shown in Figure 2.

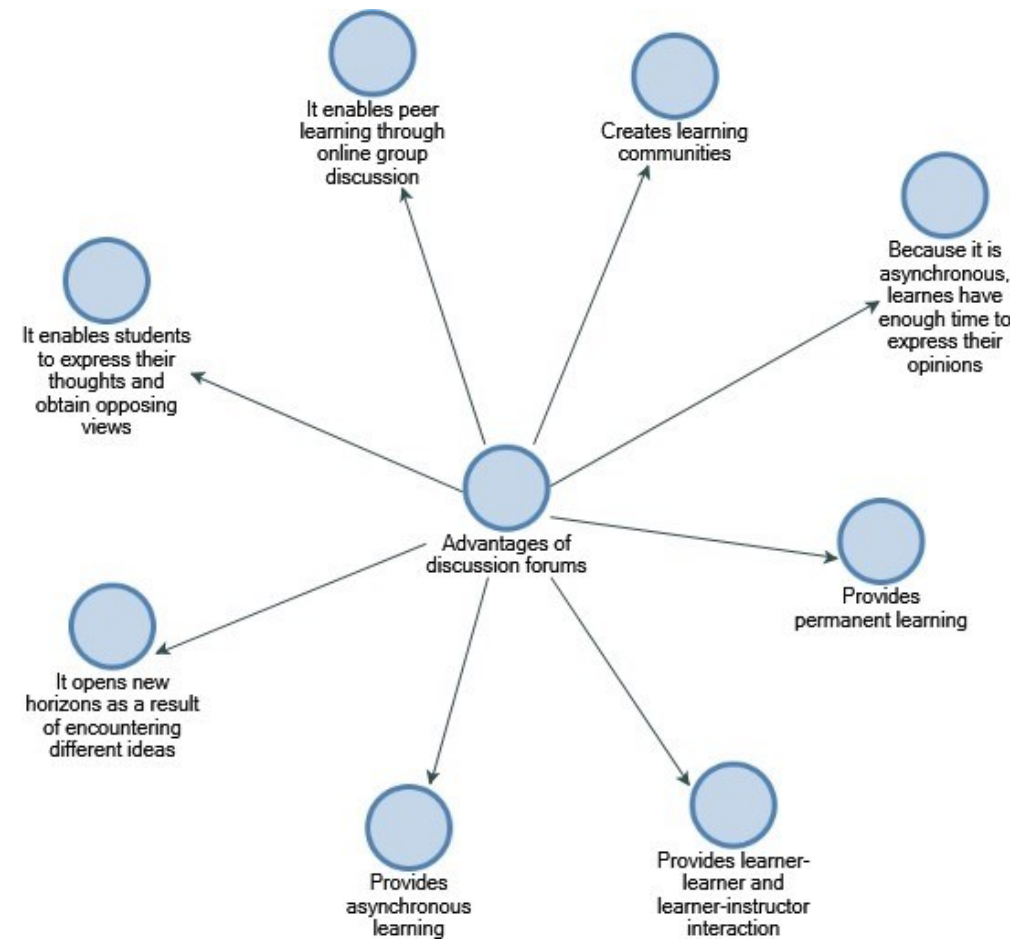

Figure 2. Advantages of discussion forums 
One of the sub-themes that stand out from the views obtained under this theme is "It enables peer learning through online group discussion". The views obtained under this theme are as follows:

“...In these environments, learning can also take place through peer learning." P1

"....In these environments, learners can provide a learning experience through peer learning. They can obtain different information from their instructor in the context of subject or study. They can provide confirmation of true or false information here." $\mathrm{P} 3$

Another sub-theme highlighted under the relevant main theme was the theme of "Provides learner-learner and learner-instructor interaction". The view obtained under this theme are as follows:

"...Learners can get detailed information about a topic from both the instructor and other learners. ” P5

Another sub-theme highlighted under the Advantages of discussion forums main theme is "It enables students to express their thoughts and obtain opposing views". The views obtained under this theme are as follows:

“...Considering the discussion forms as an environment where all participating learners can present their ideas and all other learners can receive these ideas, they can provide enormous advantages." $\mathrm{P} 1$

"...It is also important for the learners to share their thoughts with other learners, to know what the learners who have similar or opposing views to them, and to enable the learners to brainstorm." $\mathrm{P} 4$

\subsection{Views of Field Experts on the Drawbacks of Discussion Forums}

The last research question posed to field experts within the scope of the study addressed the disadvantages of discussion forums in online learning environments. The opinions obtained in this context are shown in Figure 3.

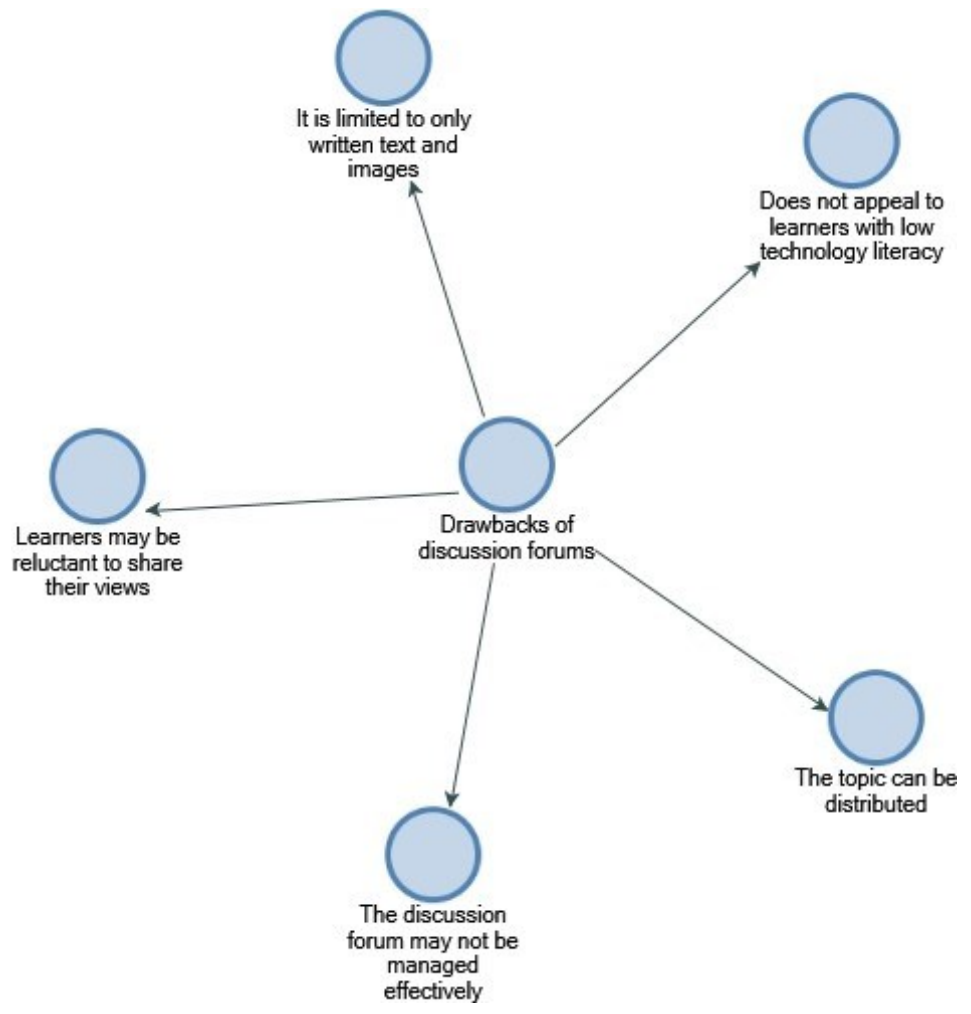

Figure 3. Drawbacks of discussion forums 
At this point, one of the prominent sub-themes is "The discussion forum may not be managed effectively". The views obtained under this theme are as follows:

"...As a limitation, it can be said that the instructor does not give feedback. Because if learners cannot get feedback on what they wrote, wrong learning may occur. In order to prevent wrong learning, immediate feedback should be given." P3

"...The limitation is that it must be constantly followed by the instructors. Otherwise, if the discussion moves away from context and goes in different directions and learners misinform each other, it may lead to learning of wrong information. However, as with learners, instructors may see this as an extra workload." $\mathrm{P} 1$

Another sub-theme highlighted under the related main theme is "Does not appeal to learners with low technology literacy". The views obtained under this theme are as follows:

"...It is also possible that individuals who do not have or have little Internet usage habits do not actively participate in discussion forms. " P6

“...Lack of experience with online discussion forums also leads to different learner profiles. In this way, learners' participation and interaction are different from each other." P5

\section{Discussion, Conclusion and Suggestions}

Within the scope of this study, which received opinions from field experts about the usability of discussion forums in online learning environments, it was concluded that discussion forums are effective learning materials that can be used in these environments. In this context, it can be said that permanent learning can be achieved in discussion forums where instructors support social relations between learners by guiding them. Similar to this result, Chau and Xu (2012) stated that discussion forums are an important tool for effective learning in online learning environments. In addition, it can be stated that discussion forums that provide asynchronous learning are a suitable tool for learners to learn at their own learning pace. In this context, So (2009) emphasized that discussion forums allow learners more time to reflect their own ideas and respond to other learners in the learning process. Besides, Loncar et al. (2014) stated that discussion forums are a suitable tool for online learning environments due to this feature.

One of the most emphasized issues within the scope of the use of discussion forums is that this tool can be managed effectively and thus prepare the ground for discussions between learners. At this point, Kılınç (2020) stated that discussion forums where online group discussions are held should be divided into manageable groups. In this context, it was stated that discussion forums should consist of a maximum of 150 learners as stated by Dunbar (1992) in order not to show the feature of massiveness. In addition, Kilınç (2020) stated that in these environments, instructors should act within the framework of social constructivism theory and Community of inquiry theory. In addition, the following seven components were highlighted by Cheong and Cheung (2008) in order to effectively manage online discussion forums. These components; (i) presenting their own views or experiences, (ii) asking questions, (iii) showing appreciation, (iv) providing ground for discussions, (v) suggesting a new direction to discussions, (vi) inviting people to contribute personally, (vii ) to summarize the discussions that took place during the process. Therefore, it can be stated that the instructors who direct the discussion forums should consider these components.

One of the most important benefits of discussion forums used in online learning environments is that learners express their own ideas and confront opposing ideas. At this point, Hampton et al. (2017) states that learners, who also have opposing ideas by expressing their own ideas in discussion forums, gain a rich learning experience through mutual dialogues. 
Another striking result obtained within the scope of the study is that discussion forums can be used effectively in flipped classroom technique, which is one of the effective techniques that can be applied in online learning environments. At this point, related resources can be presented to learners by contacting learners through discussion forums in online learning processes. In this way, it can be ensured that the learning processes are passed more efficiently by ensuring that learners come prepared to the subject given in the course.

Regarding the drawback of discussion forums used in online learning environments, it is emphasized that learners may not express themselves as they wish and may not have the necessary technology literacy. However, an important limitation is that the discussion environment cannot be managed effectively. At this point, Osborne et al. (2018) emphasized that in discussion forums that are not managed effectively, the issue can be dispersed and learners will not continue to discuss. In this context, it can be stated that attention should be paid to the design of discussion forums. Therefore, it is an important point to keep discussions manageable. At this point, machine learning algorithms can be developed to provide uninterrupted support by disabling the human factor for unmanageable large groups. In this way, using artificial intelligence, it can be made possible to manage the discussion forum as a human being should. On the other hand, links that can support the discussions with multimedia elements can be used so that discussion forums are not only dependent on written texts and visuals.

\section{References}

Altinpulluk, H., Kilinc, H., Firat, M., \& Yumurtaci, O. (2019). The influence of segmented and complete educational videos on the cognitive load, satisfaction, engagement, and academic achievement levels of learners. Journal of Computers in Education, 1-28.

Black, L. W., Wesler, H. T., Cosley, D. and DeGroot, J. M. (2011). Self-governance through group discussion in Wikipedia: Measuring deliberation in online groups. Small Group Research, 42, 595-634.

Chau, M. and $\mathrm{Xu}, \mathrm{J}$. (2012). Business intelligence in blogs: Understanding consumer interactions and communities. MIS quarterly, 36(4).

Chen, F. C. and Wang, T. C. (2009). Social conversation and effective discussion in online group learning. Educational Technology Research and Development, 57(5), 587-612.

Cheong, C.M. and Cheung, W.S. (2008). Online discussion and critical thinking skills: A case study in a Singapore secondary school. Australasian Journal of Educational Technology, 24(4), 556-573.

Creswell J. W. (2003). Research Design: Qualitative, Quantitative and Mixed Methods Approaches. Thousand Oaks, CA: Sage.

Dunbar, R. I. (1992). Neocortex size as a constraint on group size in primates. Journal of Human Evolution, 22(6), 469-493.

Gerosa, M. A., Filippo, D., Pimentel, M., Fuks, H. and Lucena, C. J. P. (2010). Is the unfolding of the group discussion off-pattern? Improving coordination support in educational forums using mobile devices. Computers \& Education, 54, 528-544. doi: 10.1016/j.compedu.2009.09.004.

Green, R. A., Farchione, D., Hughes, D. L. and Chan, S. P. (2014). Participation in asynchronous online discussion forums does improve student learning of gross anatomy. Anatomical sciences education, 7(1), 71-76. 
Hampton, D., Pearce, P. F. and Moser, D. K. (2017). Preferred methods of learning for nursing students in an online degree program. Journal of Professional Nursing, 33(1), 2737.

Hew, K. F. and Cheung, W. S. (2008). Attracting student participation in asynchronous online discussions: A case study of peer facilitation. Computers \& Education, 51(3), 11111124.

Jonassen, D. H., Davidson, M., Collins, M., Campbell, J. and B. B. Haag. (1995) Constructivism and computermediated communication in distance education. The American Journal of Distance Education, 9(2), 7-26.

Kılınç, H. (2020). Çevrimiçi Grup Tartışmalarının Öğrenenler Üzerindeki Etkisinin Çeşitli Değişkenler Açısından İncelenmesi: Anadolu Üniversitesi Açıköğretim Fakültesi Örneği. [Investigation of the Effect of Online Group Discussions on Learners in Terms Of Various Variables: The Case Of Anadolu University Open Education Faculty] Doctoral dissertation. Anadolu University, Turkey.

Kilınc, H., \& Yuzer, T. V. (2015). Context aware ubiquitous learning milieus in distance learning. International Journal on New Trends in Education and Their Implications, 6(3), 102-111.

Knowlton, D. S. (2002). Promoting liberal arts thinking through online discussion: A practical application and its theoretical basis. Educational Technology \& Society, 5(3), 189-194.

Loncar, M., Barrett, N. E. and Liu, G. Z. (2014). Towards the refinement of forum and asynchronous online discussion in educational contexts worldwide: Trends and investigative approaches within a dominant research paradigm. Computers \& Education, 73, 93-110.

Miles, B. M., Huberman A. M., (1994). Qualitative data analysis: An expanded source book (2.nd edition). California: Sage Publications.

Osborne, D. M., Byrne, J. H., Massey, D. L. and Johnston, A. N. (2018). Use of online asynchronous discussion boards to engage students, enhance critical thinking, and foster staff-student/student-student collaboration: A mixed method study. Nurse education today, $70,40-46$

Roschelle, J. A. (1992). Learning by collaborating: convergent conceptual change. Journal of the Learning Sciences, 2(3), 235-276.

Rowntree, D. (1995). Teaching and learning online: a correspondence education for the $21 \mathrm{st}$ century? British Journal of Educational Technology, 26(3), 205-215.

Schiek, D. and Ullrich, C. G. (2019). Using Web Forums for Qualitative Inquiries: Empirical Findings on the Conditions and Techniques for Asynchronous Online Group Discussions. The Qualitative Report, 24(13), 5- 16.

So, H. J. (2009). When groups decide to use asynchronous online discussions: collaborative learning and social presence under a voluntary participation structure. Journal of Computer Assisted Learning, 25(2), 143-160.

Yıldırım, A. ve Şimşek, H. (2011). Sosyal Bilimlerde Nitel Araştırma Yöntemleri (8. Basım). Ankara: Seçkin Yayınları

Vygotsky, L. S. (1967). Play and its role in the mental development of the child. Soviet Psychology, 5(3), 6-18. 